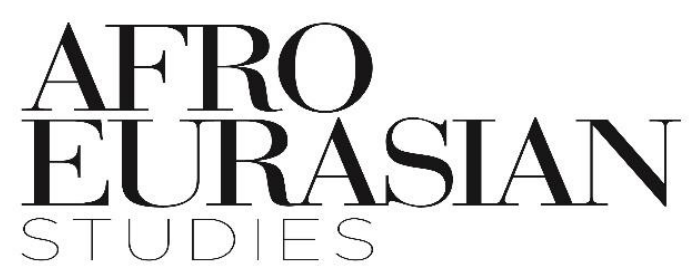

[AFES], 2019, 8 (1): 124-144

\title{
The Role Of Gender And Women In Political Institutions In Africa: A Case Of Political Parties
}

\begin{tabular}{||c|}
\hline \hline Israel Nyaburi NYADERA \\
PhD Candidate, Ankara Yildirim Beyazit University Department of Political Science and \\
Public Administration \\
inyadera@gmail.com \\
Orcid Id: $0000-0002-0432-6935$ \\
Michael Otieno KISAKA \\
MA, Hacettepe University Department of Sociology \\
kisakao@yahoo.com \\
Orcid Id: $0000-0002-0432-6935$ \\
\hline \hline
\end{tabular}

Article Information

Article Types : Research Article

$\begin{array}{ll}\text { Received } & : 13.12 .2018 \\ \text { Accepted } & : 29.03 .2019 \\ \text { Published } & : 29.03 .2019\end{array}$

Pub Date Season: March 2019

Cite as: NYADERA, I , KISAKA, M . (2019). The Role Of Gender And Women In Political Institutions In Africa: A Case Of Political Parties. Afro Eurasian $\begin{array}{lllll}\text { Studies, } & 8 & (1), & 124-144 . & \text { Retrieved }\end{array}$ http://dergipark.gov.tr/afes/issue/44214/496602

Plagiarism: This article has been reviewed by at least two referees and scanned via a plagiarism software.

Copyright () Published by MUSIAD- Ataköy 7-8-9-10 Mah. Cobancesme E5 Yanyol Cad. No:4 Bakirkoy, 34158 Istanbul / Turkey Tel +90 (212) 3953302 Fax +90 (212) 3950001 aestudies@musiad.org.tr 


\title{
The Role Of Gender And Women In Political Institutions In Africa: A Case Of Political Parties
}

\begin{abstract}
The democratization process in Africa opened up space for the emergence of several political parties across the continent as most countries moved from oneparty rule to multi-party democracy. This tectonic shift signaled a new beginning in the political arena, and there were expectations that equal representation in the political sphere would be a by-product of the democratization process. This paper underscores the challenge of gender inequality in representative politics and as it would be expected in patriarchal societies; women shoulder the brunt of marginalization in the political arena. It argues that despite the inclusion of gender-responsive texts in political parties' manifestoes and constitution, the gender gap is still burgeoning. It recommends that political parties should come up with pragmatic strategies to enhance gender equality and cease to include gender texts as mere political rhetoric.
\end{abstract}

Key Words: Gender Inequality, Political Parties, Feminism, Africa 


\section{Introduction}

The intersection between gender and politics is one that has been widely studied in the recent past and interestingly; this intersection has also been linked to general development. One common denominator that has persisted in all these is the notion of inequality with regards to gender. In economic discourse, it has been about unequal access to economic opportunities, credit, and the market and in the political discourse, which is salient to this paper; the core theme has been uneven representation-gender gap-between men and women. Indeed, even more, as global trends have indicated that more women participate and are involved in critical decision making positions the gender gap has continued to burgeon (Tripp et al., 2008).

Several explanations have been forwarded to substantiate the widening gap. According to Britton (2000), available literature has alluded to the notion that low the unequal representation in the political sphere is due to time constraints since women are preoccupied with maternal duties like child care as well as other wifely duties (Britton 2000). Additionally, Tripp (2000) has attributed unequal representation to historical, social structures that served to marginalize women through discriminatory norms and rules which excluded them from formal politics. He goes ahead to argue that the organization of the state, which was mostly male-dominated, made it impossible for women to mobilize and participate in political contests (Tripp 2008).

With the beginning of multi-party democracy in Africa in the early 1990s, political parties became salient institutions in the political discourse and focused turned to the role of these parties in creating and sustaining unequal representation. As will be seen in the later sections of this paper, political parties became conscious of this challenge and took measure led them to include gender-responsive statements in their policy programs, manifestoes and even constitutions. But even with this change of gear, whether these statements were meant to incorporate more women in political and other key decision-making positions within the parties' organs or just mere campaign strategies remains a puzzle. But with the burgeoning under-representation of women, it is easy to dismiss all these as political rhetoric (IDEA, 2013). 
This paper underscores the challenge of unequal representation of women in political discourse as the main issues that political parties, especially in Africa, have been grappling with over the last decades. We adopt a qualitative approach and analysis of secondary data like party constitutions and manifestos, as our methodological orientation. Moreover, to further highlight how unequal representation is produced and sustained, institutional feminism theory is used as the framework within which elaborate explanations can be drawn. But significantly a look into the role of women in politics is significant to illuminate the active role women have played irrespective of their continued dismal representation. One of the significant findings is that even though some political parties tend to promote political empowerment of women and include genderresponsive texts in their manifestos, gender inequality is still a challenge. This could be in part caused by unclear or lack of policy documentation of gender equality, the absence of rules and regulations that enhance nomination and selection of women as candidates for a various position within and outside the party.

\section{Theoretical Framework}

Explaining unequal representation between men and women in electoral politics and other public offices as well as other key decision-making positions has continued to exercise the mind of scholars of social science. Importantly, since it is women that have suffered the brunt of unequal representation, feminists have taken the lead to explain the existing phenomenon. Particular to feminism, institutionalists have traced the challenge of under-representation within the framework of institutions through institutionalism theory.

The question amongst institutional feminist has been how to incorporate a feminist approach to study various political outcomes like gender imbalance in electoral politics and another process that occur within and between institutions. Accordingly, two possible links to this question: the first one involves predicting future developments regarding gender imbalances and explaining the gender outcomes in the current state or order. All these require identification of specific contexts, a collection of sound data and analysis of available evidence 
as well as theorizing prevailing power relations-but of course through a feminist lens.

For feminists, institutions like political parties are gendered, and through the analysis of these institutions, serious questions about power relations can be answered. This approach enables the illumination of changes in the status of women in politics and public life (Connell, 1990:31). In this regard, institutions provide rules and shape social and political life. According to Hall (1986:7), institutions are essential for generation and organization of ideas as well as interests which are translated to formal rules or standards of operations (Hall, 1986:35). Political parts, as institutions, generate the principles, ideas, and norms that strengthen them and enable the evaluation of their attempts to change a given situation in a political context. In short, institutions like political parties establish the rules of the game and the true meaning of these rules are manifested in the ensuing interactions that occur within and between various organizations (March and Olsen 1989:2).

This paper adopts a feminist institutionalism theory that attributes the unequal representation to norms and ideas that exist within institutions. This paper finds feminists' institutionalism theory to contain within its fingerprints the capacity to analyze and make elaborate explanations regarding gender relations as well as the processes that produce and sustain these relations.

\section{Methodology}

This paper utilizes qualitative methods to analyze collect and analyze secondary data. Examination already available literature on gender issues within the political sphere was done, and importantly a focus was also given to political parties' manifestoes, constitutions, and strategic programs. We focused on political parties in Kenya, Tanzania, and Ethiopia. Kenya and Tanzania were chosen since they have been stable democracies for a long time. On the other hand, political parties in Ethiopia were examined to determine whether genderresponsive strategies are reflected in near-stable democracies.

\section{Women And Politics In Africa}


The role of women in Contemporary politics can be traced back to pre-colonial but most significantly in colonial period, a period in which women participated in the decolonization process of the continent through various activities both political like forming rebellion groups as witnessed in the coastal region of Kenya and apolitical like offering moral support to the liberation fighters. In Nigeria and Tanzania, women played an active role in organizing protests against colonial regimes that levied high taxes. These protests were either done separately through women's local organizations or as community groups that incorporated both men and women (Waylen, 2007:12).

Even with the exploitative nature and brute force of colonial powers, women continued to organize themselves to resist colonial rule in several countries. However, their resistance capabilities and success remained limited (CoqueryVidrovitch 1997:254). Cases of women leaders being killed have littered the history of women struggle during the colonial era. Kimpa Vita of Congo is a case in point of women's predicaments. As a religious leader who wielded colossal following, the colonial powers had her killed due to what they considered as a threat to their administration. This points to the dismal results of women's struggle, but it's also a reflection of tenacity and courage displayed by women in resisting colonial rule (Wipper 1989:123 -25).

Even though decolonization of the continent is regarded as a huge success, but it had insidious effects of participation of women in the political arena. The 1970s and 1980s were characterized by a decline in women participation in politics and general political process like elections due to the emergence of dictatorship and military regimes that confined the position of women to the homes. But their low participation was compounded by other factors like high levels of illiteracy and poor health which worked in collaboration and sometimes in isolation. But with the emergence of the democratization process in the early 1990s, women used this period to bring their plights to the world's attention. Even at this time, the general political environment was encapsulated with immense fear following numerous cases of political assassinations and forced disappearance which worsened the already existing challenge of gender inequality in political representation (Wipper 1989: 122 -25). 
Despite all these, women across sub-Saharan Africa have continued to organize through democratic processes for political action. In 1999, women in Namibia organized themselves to write what was termed as women manifesto whose aim was to encourage more women to take part in politics and elections. But the salience of this manifestation, which is also important in this paper, is that it petitioned political parties and the president to nominate and appoint more women to key ministerial positions. This resulted in an increase in the number of women legislators from a paltry $19 \%$ to $27 \%$ in the 1999 elections contest (Frank 1999:43).

In Kenya women equally played an essential role in bringing to light violence against women following the heated presidential campaigns in 2002 and subsequent hotly contested results of 2007 and 2013 (Good 2002). Moreover, they lobbied for more women positions in parliament and government. Their actions also, they were subsequently incorporated into the team that drafted the new Kenyan constitution that was promulgated in 2010. In the Central African Republic, women petitioned for more slots in the transitional government in 2003, in which more positions were allocated to women through the intervention of external actors UN Integrated Regional Information Networks (2003). In Guinea, women objected the increase of prices of consumer commodities forcing the president to give in to their demands (UNIRIN, 2003:4)

The ripple effects of women's actions reverberated across the continent as the increase in women's participation in political process, which was characterized by the election of female prime ministers in Sao Tome, Senegal, and Mozambique. Ellen-Sirleaf Johnson was elected the president in Liberia in an election that went down the annals of sub-Saharan African history to have produced the first female president (Tripp, 2001: 68). The regions legislative representation of women in Africa increased from 0.94\%, which was the lowest in the world, to $7.78 \%$ in the $1990 \mathrm{~s}$ as a result of women's action which ran parallel to the democratization process which began in earnest in early 1990s. Two decades later, this proportion doubled to $17.4 \%$ with the increased participation of women political institutions and processes. 
Accordingly, this increased participation should not be a surprise as women engagement in social, economic and political activities within local organizations. Contrarily, this increase should not be misconstrued to mean equal representation. Gender inequality in many African countries is still at its lowest despite palpable efforts to overcome this challenge. Political parties are again faced with the daunting task of coming up with policy frameworks that can adequately address this question.

\section{Gender Issues In Politics Of Representation}

The concept of gender, in itself, is one of the most contentious issues in the entire political infrastructure and it would be incredibly impossible to imagine political institutions that disregard issues of gender. Scholars have been therefore attracted to the investigation of the intersection between gender and politics and how gender issues are responded to within the political infrastructure. From the inception scholarship that endeavored to investigate this intersection, particularly the assiduous low representation of women in traditional public institutions, have primarily focused on the society and the state at large. At this point, the issue of low women representation took center stage.

But this scholarship transmogrified with time in response to the ever dynamic political environments in many countries and academic interests shifted to the burgeoning political advocacy and activism that emerged across the globe. However, in a significant number of studies, the focus has been on the enthusiastic pursuit of universal suffrage the United States and England. In both countries, political advocacy and activism played essential roles and women were also at the organization and execution of such momentous political activities. In all these, the issues of low women representation, institutionalization, and promotion of gender equality as well as the increase of women presence in legislative and state organizations have been given prominence.

Igniting this endeavor, the last four decades witnessed tremendous developments with regards to institutional change that sought to address these gender issues-with significant effects on women in terms of gender equality and 
gender relations within the state organization. These developments were byproducts of a global wave of democratization that came along with the reorganization of several welfare states thus producing processes like decentralization, regionalization and constitutional reforms (Banaszak et al. 2003:32). It is important to note that state restructuring has been a significant democratization process in most countries, both violent and peaceful environments leading to new developments in Latin America, Europe, South Asia and Africa (Waylen 2007:7). Throughout these developments, calls for better gender relations and gender equality have been part of the broader discourse within the frameworks of democratization and modernization, as new global norms have spread through various networks and institutions (Krook 2009; Towns 2010:11).

It is clear that institutions have been at the center of the gender question, but early feminists disregarded the role of institutions in reproducing and sustaining unequal gender relations. In particular, gender inequality was considered to exist at the micro level through the ubiquitous stratifying structure of patriarchy that characterized most societies (Witz \& Savage 1992). In this case, large institutions like the political parties, therefore, did not play a role in reproducing the unequal gender relations but somewhat were only viewed as a reflection of patriarchal practices. In this line, Ferguson's (1984) provides a critique of the bureaucracy in which he illuminates on the state's institutions as well as the state's administrative structure as innately patriarchal.

In tandem with these developments, gender has also assumed a more sophisticated understanding of political discourse. Focus has shifted to the individual level, and attention has been exclusively given to women as a path to the analysis of primary structures that buttress gender disadvantages within various institutions (Duerst-Lahti and Kelly 1995:71). Conversely, since gender is socially constructed, focusing on the place of women in politics can just provide a useful window that offers a glimpse on the patterns of access that are largely gendered but cannot provide valuable explanations with regards to the persistent gender inequalities and other practices of exclusion that are situated within the purview of political institutions (Mackay 2004:16). Therefore the center of gravity has recently changed from 'women and politics' 
to the conceptualization of gender and politics within the framework of political institutions (Beckwith 2005:32). This shift brings to light the varied ways through which gendered and unequal power relations are constructed, sustained and shaped through the existing political institutions (Beckwith 2005:38).

Even as the scholarship of gender issues increases, there have been certain distinct features that are palpable. Significantly there have been attempts to put to light the nebulous concept of politics into perspective. The definition of politics has thus been expanded to incorporate not only the formal procedures regarding elections and government but also informal activities that occur within interpersonal relations and social movements which are concerned with gender relations in pursuant of political change (Phillips 1998). Consequently, serious questions about the nature and scope of politics have been raised and in particular, the distinction between political and non-political issues (Kulawik 2009). But all these still underscore the question on equality in representation with women regarded as insignificantly represented.

Significantly and essential to this paper, scholarship has involved the analysis of the impact of elections and electoral systems in general on women's political representation as well as exploring the responsibilities of political parties in enhancing and restraining behavior of women as activists and legislators (Kittilson 2006:22). It is without a doubt that one of the unrelenting themes in world democracies has been the continued deficit of women's influence in politics. Political parties, in particular, have constricted the voices of women in critical decision making and leadership roles and in some cases, these are entirely imaginary. These occurrences come in the backdrop of increased women population, continuous mobilization of women by political parties as voters and active followers and the use of women as campaign strategies. This makes it apparent that there has been a failure to translate women involvement in peripheral activities to their inclusion in political parties' policies and decision making.

Since the representation of women has been one of the main issues identified within the political discourse, the question, therefore, cannot be whether they can undertake pole positions in political parties structures because their contribution to political parties has already been acknowledging as immense. 
The questions then become how political parties can intervene on the issue of gender inequality to amplify their voices in key decisions and to ensure that their numbers translate to their significance in key leadership roles in politics.

\section{Role Of Political Parties In Promoting Gender Equality}

In the last two decades, the democratization process in Africa has been characterized by an increase in the number of political parties as the primary institutions that organize themselves to initiate and execute political and social change. This does not offer a blind eye to other organization like civil societies which have served as bastions of liberal democracy. Political parties have been recognized mainly by advocates of gender equality and other stakeholders as central institutions that should play essential roles in achieving gender parity. In this regard, significant advancements have been achieved in the diffusion of universal norms and global undertakings to rectify gender inequalities in politics and power relations (IDEA, 2007: 19).

These global undertakings have been underpinned in international frameworks such as sustainable development goals, Beijing Declaration and Platform of Action and Convention on the Elimination of All Forms of Discrimination Against Women (CEDAW). In Africa, these undertakings are underpinned through the implementation of frameworks like the 2007 African Union Charter on Democracy, Elections and Governance and African Commission on Human and Peoples' Rights (ACHPR), Protocol to the African Charter on Human and Peoples' Rights on the Rights of Women in Africa. But given the salience of political parties as vehicles of enhancing gender parity in liberal democracies, political parties are emerging as central components of gender-responsive programmes. In this case, it becomes clear that the need to merge global and national commitments on gender parity in politics, decision making, and leadership as well as promises made at the party levels cannot be emphasized enough. Political parties hence provide a unique platform that enables individuals to access political power and also provides an avenue in which the decision-making process begins (IDEA, 2007:22).

Based on the centrality of the political parties, there has been a consensus both at the national and international level that political parties must be involved to 
achieve gender parity. According to Ballington and Karam (2005), Political parties are essential in the performance of democracies, and they are among the leading institutions that enhance participation in electoral processes as well as increase the level of accountability. In short, political parties provide the muchneeded support to candidates and are conduits that involve people in public life (Ballington and Karam 2005:4).

Even while there is a belief that political parties are essential in promoting gender parity in leadership roles and other representative positions, most political parties in Africa are weak and are faced with numerous challenges including structural, ideological and institutional problems which can engender an emergence of unconventional democratic values (Roza, et al, 2011). Moreover, political parties are primarily regarded as democratic even when the female population is not adequately represented in crucial decision making and leadership positions, a situation that has furthered the challenge of gender inequality in political discourse. With the realization of these defects, political parties have worked towards placing the issue of gender equality within their institutional frameworks by developing gendered policies within their policy documents, but these cannot serve as yardsticks for viewing gender equality (Matland, 2006).

\section{Gender Commitments in political Parties' Policy Documents}

The centrality of political parties in promoting gender equality in representation is one that cannot be emphasized enough. Therefore, it is imperative that political parties should have within their policy documents commitments that are geared toward achieving equality. Availability or lack of such obligations then becomes essential benchmarks through which political parties can be gauged. Given the primacy of political parties, their commitments to gender equality are also an acceptance of existing gender gaps and the need to initiate responsive strategies to rectify the existing imbalance (IDEA).

This section assesses how the main political parties in Kenya, Tanzania, and Ethiopia have incorporated commitments to gender equality within their policy frameworks. These three countries are not a complete representation of the 
entire continent, but they showcase the extent to which gender equality commitment are pursued within political parties in Africa.

\section{Assessing Political Parties' Gender Equality Commitments in Kenya}

\section{Orange Democratic Movement (ODM)}

The constitution of the Orange Democratic Movement highlights key commitments to gender equality. Its objective with regards to gender parity is stipulated as one which seeks to pursue and promote women participation in the national development and public affairs. The party endeavors to use affirmative action to bring women participation to the center of its activities and also commits to respect CEDAW in the promotion of gender equity and equality (Articles $4.15 \& 4.16$ ).

Its manifesto also addresses the issue of women empowerment which the party seeks to achieve through legislation, championing the disbandment of oppressive practices, education, and elimination of discrimination against women and girls. In pursuit of women empowerment, the party also commits to ratify conventions on the rights of women and work towards ensuring $30 \%$ of women are represented in local government, national parliament as well as in other key decision making and governance positions.

\section{Jubilee Party}

In its constitution, the Jubilee party aims at promoting the rights of women and ensuring that there is full participation of women in their party affairs (Articles $2 \mathrm{~b}$ and $2 \mathrm{c}$ ). Just like the Orange Democratic Movement, the party also seeks to ensure that $30 \%$ of women are represented in all its organs. Besides, it manifesto also reiterates its commitment to providing the full participation of women in its activities and pledges to engage other essential stakeholders to promote gender equality.

\section{National Rainbow Coalition (NARC)}

The NARC constitution stipulates the parties vision as one that seeks to enhance participation of women in national politics and to pursue $30 \%$ representation of women in all elective positions using civic education- also highlighted in the party's gender policy. Its manifesto also illuminates on the issue of gender 
equality, and it highlights the party's endeavor to ratify all international conventions that seek gender equality, ensure availability of gender mainstreaming frameworks in all institutions and promote women empowerment through availing equal opportunities to men and women. NARC is equally a unique political party in Kenya since it is headed by a Woman who also used the party to vie in previous presidential elections

\section{Assessing Political Parties' Gender Equality Commitments in Tanzania}

\section{Chama cha Demokrasia na Maendeleo (CHADEMA)}

CHADEMA's constitution asserts its commitment to eliminate all forms of gender discrimination. Particularly, in its objectives, the party seeks to promote, educate, and promote human rights as stipulated in Universal Declaration of Human Rights and all other international charters that promote and protect such rights (Chapter 4)

In its manifesto, the party reiterates its commitment to protecting the rights of the disabled, children and women. In line with gender equality, the party seeks to initiate national programs that are geared toward improving and sustaining the welfare of women and abolish punitive laws that hinder this endeavor. The establishment of the Women's Council that is mandated to promote the rights of girls and women is also a commitment in the manifesto.

\section{Chama Cha Mapinduzi (CCM)}

The constitution of CCM asserts the equality of all citizens regardless of gender orientation. In this regard, all citizens are entitled to the recognition and respect of their human dignity (Articles 4.1 and 4.2). Interestingly, the constitution commits to protecting human dignity without a specific commitment to promoting gender equality in political representation and leadership.

On the other hand, its manifesto seeks to enhance gender equality and political participation of women in all its organs. The party also aims to rise against discriminatory laws, customs, and traditions by abolishing laws that hinder the rights of women.

National Convention for Construction and Reform-Mageuzi 
The party's constitution provides distinct provisions on gender. In this regard, the party aims at ensuring equality between men and women (Article 13). The party also endeavors to use affirmative action to support and protect marginalized groups, in which women are also incorporated, to enhance their social economic and political status. All party members, irrespective of gender and religion, are entitled to elected to various positions within the party organs (Article 10.1).

The party's manifesto seeks to ensure $50 \%$ of women are represented in all party and elective positions to achieve gender equality. Besides, it promises to be a signatory to all international charters that promote gender equality and human rights.

\section{Assessing Political Parties' Gender Equality Commitments in Ethiopia}

\section{Unity for Democracy and Justice Party}

The party has a program document that stipulates its principles. Amongst them is the principles is the respect for the rights of children, women, the elderly and the disabled (Article 1.1.12). It also seeks to uplift the status of women by overturning an entrenched notion that regards women as inferior. It further commits to support women through civic education to increase their participation in political, social and economic affairs (Article 3.4.72).

\section{Ethiopian People's Revolutionary Democratic Front (ERDF)}

The party has within its strategic program a provision to promote gender equality. It acknowledges the existence of gender-biased norms that have hindered economic and social development, and to propel rapid growth, there is a need to protect the rights of women and workers.

\section{Ethiopia's Democratic Party (EDP)}

The party's strategic document illuminates on its objective to enhance and bring to real gender equality and empower women through well affirmative action, education and a just legal and political system that promotes participation of women in an elective position. 
From the preceding, it is evident that political parties are conscious of the need for enhancing gender equality in representative positions and are committed to curbing the menace of under-representation of women. This is reflected in their constitutions, manifestoes and strategic programs which elaborate measures that the parties seek to pursue. But in spite of this, participation and representation gap between men and women is still burgeoning Ballington and Karam (2005). This can be attributed to two main reasons. On the one hand, there is lack of implementation and enforcement measures to bring their commitments to fruition and on the other hand, gender issues written on manifestoes only serve as election rhetoric geared towards enticing women to participate in the voting process. In this regard, achieving equal representation continues to be a mirage since measures placed by political parties are only used as a benchmark for progressive intentions on paper, but in actual sense, they are merely declarations with not practical implementation. The challenge is hence exacerbated by the failure to institutionalize these gender-responsive strategies (Norris,2006)

\section{Conclusion}

The issue of gender equality in political representation is one that has received full attention from scholars and some stakeholders. Due to the nature and scope to the challenge, a number of international frameworks like Beijing Declaration Platform of Action, Convention on the Elimination of All Forms of Discrimination Against Women (CEDAW) and African Commission on Human and Peoples' Rights (ACHPR), Protocol to the African Charter on Human and Peoples' Rights on the Rights of Women in Africa, which have enabled analysis of the performance and role of political parties in advancing equality in gender. This has ignited the need for political parties to ensure that women are assured of full participation and access to various leadership and decision-making positions. This points to the salience of political parties as the main gatekeepers for women's as well as men's access to key positions within government and political positions.

Mainly, there has been a tremendous focus on the role of political parties in rectifying unequal gender representation in politics which is coupled with a broad consensus that access to leadership, decision making, and political 
positions usually start from the political party level. To this end, political parties not only become vehicles of attaining political power but also creators of a conducive environment that enables full representation and participation of both women and men.

As it has been established, through the analysis of political parties' manifestoes, constitutions, and strategic documents, political parties have some degree of awareness with regards o gender issues. However, the primary challenge lies in the ability of political parties to translate this awareness from mere political rhetoric to the realization of gender equality in politics by institutionalizing gender issues.

Indeed, there cannot be a single path to rectify the already existing gender imbalances. A look at political parties key documents-manifestoes and constitutions testifies that more work should be done to change the status of women. This can be done differently, but pragmatic strategies which are genderresponsive can be adopted by different political parties across the continent. It is therefore clear that commitments and texts on gender found in parties' documents cannot be enough measures in curtailing the burgeoning gender gaps in the political sphere and the parties must not only acknowledge the challenge but must transform these commitments to effective strategies. 


\section{References}

Banaszak, Lee Ann, Karen Beckwith and Dieter Rucht (2003), 'When Power Relocates: Interactive Changes in Women's Movements and States', in Lee Ann Banaszak, Karen Beckwith and Dieter Rucht (eds), Women's Movements Facing the Reconfigured State, Cambridge: Cambridge University Press, pp. 1-29.

Beckwith, Karen (2005), 'A Common Language of Gender?', Politics \& Gender, 1: 1, 128-37.

Britton, Hannah E. (2002). The incomplete revolution: South African women's struggle for parliamentary transformation. International Feminist Journal of Politics 4 (1): 43-71. 2005. From resistance to governance: Women in the South African parliament. Champaign: University of Illinois Press.

Connell, R.W. (1990), 'The State, Gender, and Sexual Politics: Theory and Appraisal,' Theory and Society, 19: 5, 507-44.

Coquery-Vidrovitch, Catherine. 1997. African women. Boulder, Colo.: Westview Press.

Duerst-Lahti, Georgia and Rita Mae Kelly (eds) (1995), Gender Power, Leadership, and Governance, Ann Arbor, MI: University of Michigan Press.

Ferguson, Kathy (1984), The Feminist Case Against Bureaucracy, Philadelphia, PA: Temple University Press.

Frank, Liz. 1999. Women challenge "government by men for men" with the Namibian Women's Manifesto. Sister Namibia 11 (3). 
Good, Regan. 2002. Rape is a prominent issue in Kenya elections. 1 April $\begin{array}{llll}\text { (accessed } & 5 & \text { August } & \text { 2003). Available }\end{array}$ fromwww.womensenews.org/article.cfm/dyn/aid/864/context/archive.

Hall, Peter A. (1986), Governing the Economy: The Politics of State Intervention in Britain and France, Oxford: Oxford University Press.

J. Ballington and A. Karam (eds), Women in Parliament: Beyond Numbers, Handbook Series (Stockholm: International IDEA, 2005), available at <http://www.idea.int/publications/wip2/>, accessed 12 November 2013

Jacobsen, K. and S. Fratzke (2016) Building Livelihoods Opportunities for Refugee Populations: Lessons from Past Practice, http://www.migrationpolicy.org/research/building-livelihoodopportunities-refugee-populations-lessons-past-practice

Kittilson, Miki Caul (2006), Challenging Parties, Changing Parliaments: Women and Elected Office in Contemporary Western Europe, Columbus: Ohio State University Press.

Krook, Mona Lena (2009), Quotas for Women in Politics: Gender and Candidate Selection Reform Worldwide, New York: Oxford University Press.

Kulawik, Teresa (2009), 'Staking the Frame of a Feminist Discursive Institutionalism', Politics \& Gender 5: 2, 262-271.

Mackay, Fiona (2004), 'Gender and Political Representation in the UK: The State of the "Discipline", The British Journal of Politics and International Relations, 6: 1, 99-120. 
March, James G. and Johan P. Olsen (2005), Elaborating the "New Institutionalism”, Centre for European Studies, University of Oslo.

Matland, R. E., (2006)'Quotas: Frequency and Effectiveness', in D. Dahlerup (ed.), Gender Quotas: a Key to Equality? (Oxford, UK: Routledge Publishing)

Norris, P., 'Comparing Legislative Recruitment', in J. Lovenduski and P. Norris (eds), Gender and Party Politics (Place: Publisher, 2006)

Phillips, Anne (ed.) (1998), Feminism and Politics, Oxford: Oxford University Press.

Roza, V., Llanos, B., and Garzón de la Roza, G., Gender and Political Parties: Far from Parity (Stockholm and Washington, DC: International IDEA and IDB, 2011), available at <http://www.idea.int/publications/parties__ and_parity/en.cfm>, accessed 12 November 2013

Sacchet, T., 'Political Parties: When Do They Work for Women', paper prepared for the United Nations Department for Economic and Social Affairs, 2005, available at <http://www.un.org/womenwatch/daw/egm/ eql-men/docs/EP.10_rev.pdf>, accessed 12 November 2013

Towns, Ann (2010), Women and States: Norms and Hierarchies in International Society, New York: Cambridge University Press.

Tripp, Aili Mari. 1994 2001a. New trends in women's political Participation in Africa. Paper presented at the workshop on democracy in Africa in comparative perspective, the Democratization Seminar, 
Institute for International Studies and the Center for African Studies, Stanford University.

Tripp, Aili, Isabel Casimiro, Joy Kwesiga, and Alice Mungwa. 2008. Women in movement: Transformations in African political landscapes. New York: Cambridge University Press.

Waylen, Georgina (2007), Engendering Transitions: Women's Mobilization, Institutions, and Gender Outcomes, Oxford: Oxford University Press.

Waylen, Georgina (2007), Engendering Transitions: Women's Mobilization, Institutions, and Gender Outcomes, Oxford: Oxford University Press.

Wipper, Audrey.1989. Kikuyu women and the Harry Thuku disturbances. Africa Journal of the International African Institute 59: 300-337.

Witz, Anne and Mike Savage (1992), 'The Gender of Organizations', in Mike Savage and Anne Witz (eds), Gender and Bureaucracy, Oxford: Blackwell, pp. 3-62. 